\title{
The Relationship Between ABO and Rh Blood Groups and COVID19 Confirmed Patients, an Observational Study
}

\author{
Ahmed Mohamed Haider Al Amadii ${ }^{1}$, Mahmoud Hamouri' $^{2}$, Amira Imsail Al Adab ${ }^{3}$ and Yahya Ethawi ${ }^{4 *}$ \\ ${ }^{1}$ Consultant Otolaryngologist, Kuwaiti Hospital, UAE \\ ${ }^{2}$ Consultant internist, Kuwaiti Hospital, UAE \\ ${ }^{3}$ Specialist plastic surgeon, Al Qassimi Hospital, UAE \\ ${ }^{4}$ Consultant neonatologist, Al Qassimi Hospital for Women's and children, UAE
}

*Corresponding author: Yahya Ethawi, NICU, first floor, Al Qassimi Hospital For

Women's and Hospital, Ministry of health and Prevention, Sharjah, UAE.

Received Date: June 29, 2020

Published Date: July 27, 2020

\begin{abstract}
This is an observational study conducted on the patients admitted to Expo Field hospital Sharjah, United Arab Emirates (UAE) with the novel coronavirus disease-2019 (COVID-19) confirmed infection between March and May 2020. This disease caused by SRAS-CoV-2 virus discovered for the first time in Wuhan, China, in December 2019 and declared as a pandemic by World Health Organization (WHO) in 2020. We looked to the ABO and $\mathrm{Rh}$ blood groups distribution in 1014 COVID-19 confirmed patients. Our results showed that blood group 0 was the most common in these patients compared to the least common which is the $\mathrm{ABO}$ blood group. This is result goes with the findings of a few other studies that observed the association between the ABO blood type and COVID-19. However, this study has many limitations such as the non-availability of blood grouping in a considerable number of patients. In addition, there is no comparison with the data of normal blood group distribution of non-COVID-19 patients.
\end{abstract}

Keywords: Blood group; ABO; Rh; COVID19; SARS-CoV-2

\section{Introduction}

In the last two months of 2019, the novel Coronavirus, later on, called SARS-CoV-2, was identified as the cause of a mysterious outbreak of unusual respiratory problems in the city of Wuhan, China. One month later, at the beginning of 2020, the World Health Organization (WHO) gave the name of coronavirus disease 2019 (COVID19) [1-4].

After the first reported case of COVID-19 in China, the infection has increased to include more than twelve million confirmed cases worldwide. Therefore, the WHO declared a public health emergency in late January 2020. Later on, characterized it as a pandemic in March 2020 [5-8].

COVID-19 infection should be suspected in patients who have a fever with or without respiratory symptoms who with lived or have traveled to infected areas, or who have had close contact with confirmed or suspected COVID-19 infection. The possibility of COVID-19 should also be suspected in cases of severe respiratory disease if no other etiology is identified. Prioritizing the testing to include hospitalized patients, symptomatic health care workers, 
and symptomatic individuals who have risk factors for a severe disease may be an acceptable option if there are no resources to test all suspected cases [9-11].

The virologic diagnosis is made by a positive reversetranscription polymerase chain reaction (RT-PCR) test for SARSCoV-2 in a nasopharyngeal swab. However, because of the limitation of this testing capacity and the possibility of false-negative testing, the diagnosis should be consistent with clinical and local epidemiologic criteria. Some serologic tests may help identify prior infected individuals but have less utility in the first weeks of infection [12-22].

Control measures of COVID19 infection must be implemented upon diagnosis and public health officials should be notified. Measures like social distancing, isolation, lockdown, wearing a mask, gloves, washing hands, and others among some of these measures [1-3, 23-25].

Hospital management includes supportive care with some investigational protocol under expiate evaluation. However, home management may be appropriate for asymptomatic patients or those with with mild symptoms that can be adequately isolated in the home. While a small percentage of patients required close and intensive care [1-3, 23-28].

Chest X-ray may be normal in asymptomatic or early or mild illness [29]. The findings of chest X-ray include consolidation with a ground-glass appearance which is usually bilateral, peripheral, and

\section{Result}

Table1: the characteristic of the 536 COVID19 patients with their ABO blood group.

\begin{tabular}{|c|c|c|}
\hline Blood Group & Number of the Patients & Percentage \\
\hline O & 193 & $193 / 536(36 \%)$ \\
\hline B & $175 / 536(33 \%)$ \\
\hline A & 131 & $131 / 536(24 \%)$ \\
\hline AB & 37 & $37 / 536(7 \%)$ \\
\hline Included patients & 536 & \\
\hline Excluded patients & 478 & \\
\hline Admitted patients & 1014 & \\
\hline
\end{tabular}

Table 2: The number of patients and their combined Rh and ABO blood group status.

\begin{tabular}{|c|c|c|}
\hline Blood Group & Number of the Patients & Percentage \\
\hline O+ & 179 & $129 / 362(35 \%)$ \\
\hline B+ & 164 & $86 / 362(24 \%)$ \\
\hline A+ & 124 & $26 / 362(7 \%)$ \\
\hline AB+ & 35 & $10 / 23(43 \%)$ \\
\hline O- & 14 & $6 / 23(26 \%)$ \\
\hline B- & 11 & $5 / 23(22 \%)$ \\
\hline A- & 7 & $2 / 23(9)$ \\
\hline AB- & 2 & $23 / 536(6 \%)$ \\
\hline Rh negative blood group & 34 & $362 / 536(94 \%)$ \\
\hline Rh Positive blood group & 502 & \\
\hline
\end{tabular}


The total patients included in the study were 1014. Of those 478 were excluded due to the unavailability of their blood group. The total number of patients with blood group tested is 536, of them 502 (94\%) have Rh-positive blood group while 34 (6\%) were
Rh negative (Table 1\&2). We found the most common blood group is 0 which occurs in $36 \%$ of the admitted patients while the least common blood group was $\mathrm{AB}$ which occurs in $7 \%$ of admitted patients.

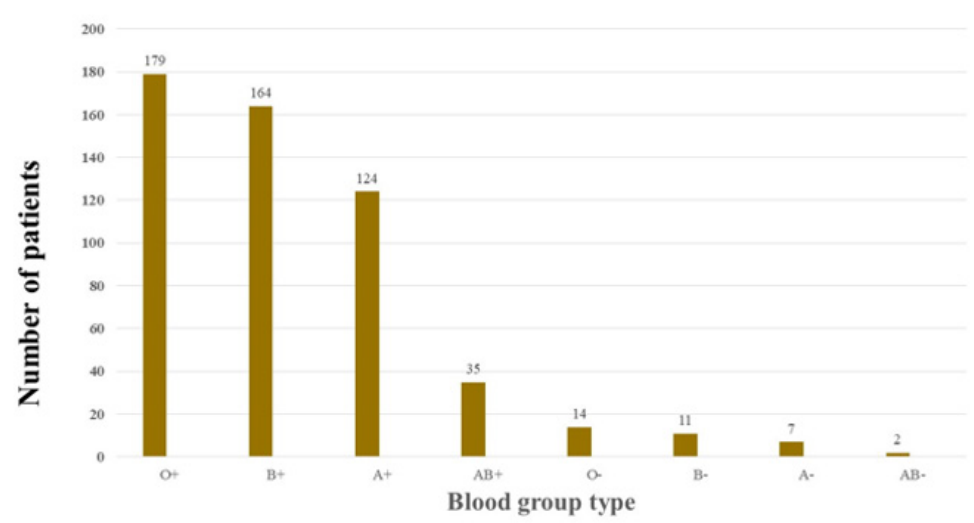

Figure 1: $A B O$ and $\mathrm{RH}$ blood groups' frequency of COVDI-19 patients

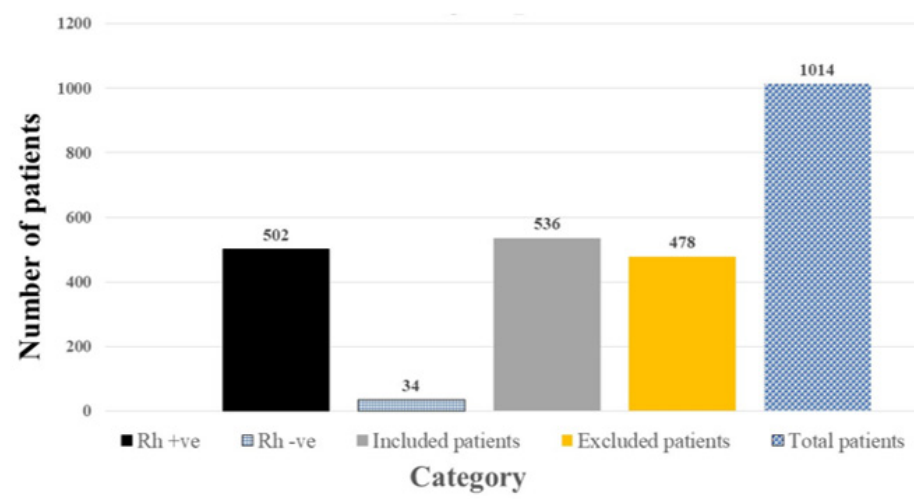

Figure 2: Total patients characteristic of Rh blood group of COVID-19 patients.

We found the Rh-positive blood group is more common than that in the Rh-negative blood group, 94\% versus 6\% percent respectively as shown in Table 2 . The most common combined ABO and $\mathrm{Rh}$ blood groups were blood group 0 positive (36\%) while the least common Combined $\mathrm{ABO}$ and $\mathrm{Rh}$ blood groups were $\mathrm{AB}$ negative $(7 \%)$ Figure $1 \& 2$.

\section{Discussion}

In the current study, we looked at the $\mathrm{ABO}$ and $\mathrm{Rh}$ blood groups of 1014 patients admitted to the Expo Field hospital of the Ministry of health and prevention, Sharjah, UAE between March, and May 2020. We found the most common ABO blood group is 0 at $94 \%$, while the least common blood group was $A B$ with $7 \%$ of total patients admitted to hour hospital. This finding might indicate the $\mathrm{O}$ group of the $\mathrm{ABO}$ blood grouping is a risk factor for getting COVID-19 infection compared to the non-0 blood group while the $\mathrm{AB}$ blood group considers protective factors against COVID19 infection. This finding is against the finding of Zhao et al findings.
The difference may be related to the sampling method as this is a simple selection method or related to the ethnicity of patients between UAE (as it is a multinational country) compared to China where the population is mainly Chinese. Another factor that might affect the result is the loss of subjects due to in availability of blood group testing in $47 \%$ of those admitted in our study. We also found the $\mathrm{RH}$ positive blood group is the most common RH blood group (94\%) compare to the Rh-negative blood group (6\%). This might reflect the normal distribution of the Rh blood group among normal individuals.

\section{Conclusion}

Our study showed that blood group 0 was the most common in these patients compared to the least common which is the $\mathrm{AB}$ blood group. This is following few other studies observations that look at the association between the ABO blood types and COVID-19. However, this study has many limitations such as the nonavailability of blood grouping inconsiderable number of patients. 
In addition, there is no data of the normal distribution of the blood groups in non-COVID-19 patients to compare with.

\section{Authors Contribution}

- The author of the primary idea, contribute to the management issue and review the report

- $\quad$ Collecting the data

- Analysis of the data and writing the manuscript in addition to the correspondence.

\section{Acknowledgement}

None.

\section{Conflict of Interest}

The authors declare no conflict of interest.

\section{References}

1. World Health Organization (2020) WHO Director-General's remarks at the media briefing on 2019-nCoV on 11 February 2020.

2. Centers for Disease Control and Prevention (2020) 2019 Novel coronavirus, Wuhan, China. Information for Healthcare Professionals.

3. World Health Organization (2020) Novel Coronavirus (2019-nCoV) technical guidance.

4. Zhou P, Yang XL, Wang XG, Hu B, Zhang L, et al. (2020) A pneumonia outbreak associated with a new coronavirus of probable bat origin. Nature 579(7798): 270-273

5. CDC COVID-19 Response Team (2020) Geographic Differences in COVID-19 Cases, Deaths, and Incidence - United States, February 12April 7, 2020. MMWR Morb Mortal Wkly Rep 69(15): 465-471.

6. McMichael TM, Clark S, Pogosjans S, Kay M, Lewis J, et al. CoVID-19 in a Long-Term Care Facility - King County, Washington, February 27-March 9, 2020. MMWR Morb Mortal Wkly Rep 69(12): 339-342.

7. Mosites E, Parker EM, Clarke KE, Gaeta JM, Baggett TP, et al. (2020) Assessment of SARS-CoV-2 Infection Prevalence in Homeless Shelters Four U.S. Cities, March 27-April 15, 2020. MMWR Morb Mortal Wkly Rep 69(17): 521-522.

8. World Health Organization (2020) Novel coronavirus (2019-nCoV) situation report -2. January 22, 2020.

9. Li Q, Guan X, Wu P, Wang X, Zhou L, et al. (2020) Early Transmission Dynamics in Wuhan, China, of Novel Coronavirus-Infected Pneumonia. N Engl J Med 382(13): 1199-1207.

10. Guan WJ, Ni ZY, Hu Y, Liang WH, Ou CQ, et al. (2020) Clinical Characteristics of Coronavirus Disease 2019 in China. N Engl J Med 382: 1708-1720.

11. Chan JF, Yuan S, Kok KH, Wang KK, Chu H, et al. (2020) A familial cluster of pneumonia associated with the 2019 novel coronavirus indicating person-to-person transmission: a study of a family cluster. Lancet 395(10223): 514-423.

12. Centers for Disease Control and Prevention (2020) Interim Guidelines for Collecting, Handling, and Testing Clinical Specimens from Persons Under Investigation (PUIs) for Coronavirus Disease 2019 (COVID-19).

13. U.S Food \& Drug (2020) Coronavirus (COVID-19) Update: FDA Authorizes First Test for Patient At-Home Sample Collection.
14. World Health Organization (2020) Coronavirus disease (COVID-19) technical guidance: Surveillance and case definitions.

15. Fang Y, Zhang H, Xie J, Lin M, Ying L, (2020) et al. Sensitivity of Chest CT for COVID-19: Comparison to RT-PCR. Radiology 200432.

16. Lee TH, Lin RJ, Lin RTP, Barkham T, Rao P, et al. (2020) Testing for SARSCoV-2: Can We Stop at Two? Clin Infect Dis.

17. Guo L, Ren L, Yang S, Xiao M, Chang D, et al. (2020) Profiling Early Humoral Response to Diagnose Novel Coronavirus Disease (COVID-19). Clin Infect Dis.

18. Zhao J, Yuan Q Wang H, Liu W, Liao X, et al. (2020) Antibody responses to SARS-CoV-2 in patients of novel coronavirus disease 2019. Clin Infect Dis.

19. World Health Organization (2020) Advice on the use of point-of-care immunodiagnostic tests for COVID-19. scientific brief, 8 April 2020.

20. Wu X, Cai Y, Huang X, Yu X, Zhao L, et al. (2020) Co-infection with SARSCoV-2 and Influenza A Virus in Patient with Pneumonia, China. Emerg Infect Dis 26(6): 1324-1326.

21. Ding Q, Lu P, Fan Y, Xia Y, Liu M, et al. (2020) The clinical characteristics of pneumonia patients coinfected with 2019 novel coronavirus and influenza virus in Wuhan, China. J Med Virol.

22. Kim D, Quinn J, Pinsky B, Shah NH, Brown I, et al. (2020) Rates of Coinfection Between SARS-CoV-2 and Other Respiratory Pathogens. JAMA 323(20): 2085-2086.

23. Wang D, Hu B, Hu C, Zhu F, Liu X, et al. (2020) Clinical Characteristics of 138 Hospitalized Patients With 2019 Novel Coronavirus-Infected Pneumonia in Wuhan, China. JAMA 323(11): 1061-1069.

24. McMichael TM, Clark S, Pogosjans S, Kay M, Lewis J, et al. (2020) COVID-19 in a Long-Term Care Facility - King County, Washington, February 27-March 9, 2020. MMWR Morb Mortal Wkly Rep 69(12): 339-342.

25. Chow EJ, Schwartz NG, Tobolowsky FA, Zacks RLT, Frazier MH, et al. (2020)Symptom Screening at Illness Onset of Health Care Personnel With SARS-CoV-2 Infection in King County, Washington. JAMA 323(20): 2087-2089.

26. James L Januzzi (2020) Troponin and BNP Use in COVID-19.

27. Thachil J, Tang N, Gando S, Falanga A, Cattaneo M, et al. (2020) ISTH interim guidance on recognition and management of coagulopathy in COVID-19. J Thromb Haemost 18(5): 1023-1026.

28. Xie Y, Wang X, Yang P, Zhang S (2020) COVID-19 Complicated by Acute Pulmonary Embolism. Images in Cardiothoracic Imaging 2(2): 1-2.

29. Wong HYF, Lam HYS, Fong AH, Leung ST, Chin TWY, et al. (2020) Frequency and Distribution of Chest Radiographic Findings in COVID-19 Positive Patients. Radiology.

30. (2020) ACR Recommendations for the use of Chest Radiography and Computed Tomography (CT) for Suspected COVID-19 Infection.

31. Simpson S, Kay F, Abbara S, Bhalla S, Chung JH, et al. Radiological Society of North America Expert Consensus Statement on Reporting Chest CT Findings Related to COVID-19. Endorsed by the Society of Thoracic Radiology, the American College of Radiology, and RSNA. Radiolology: Cardiothoracic imaging 2(2).

32. Zhao J, Yang Y, Huang HP, Li D, Gu D, et al. (2020) Relationship between the ABO blood group and the COVID-19 susceptibility. 